Volume: 12 Issue: 1 Year: 2015

\title{
Evaluating nursing students clinic stress, and coping with stress during the clinic first day of the Woman Health and Diseases Nursing clinical course ${ }^{1}$
}

\author{
Dilek Coşkuner Potur ${ }^{2}$ \\ Nevin Çitak Bilgin ${ }^{3}$ \\ Nuran Kömürcü ${ }^{4}$
}

\begin{abstract}
Purpose: This study aimed to explore the clinical stress levels, stress sources and coping strategies of Turkish male and female nursing students attending the Woman's Health and Disease Nursing clinical course on the first day.

Method and material: This cross-sectional study was conducted in March 2010 at a public university located in Istanbul. The study group included 98 nursing students. Data were collected from the nursing students in the study group using a self-report questionnaire, clinical stress questionnaire and Carver Coping scale. The data were analyses using percentages, chi-square analysis, the Mann-Whitney U test and Cronbach's alpha coefficients

Results: Approximately half of the male students (47.6\%) reported that they experienced stress since the patient group consisted of females and the majority of male students $(76.2 \%)$ stated that they were subject to gender discrimination at the clinic and there was a significant difference between the male and female students. The male and female nursing students' stress levels and Carver Coping scale total score of on the first day of the Woman's Health and Disease nursing clinical course was similar ( $\mathrm{p}>0.05)$.

Conclusions: Male students experience stress because the patient group consisted of women, the majority of male students reported that they were subject to gender discrimination and gender discrimination was a source of stress for them. Female and male nursing students experienced stress in the first day of the clinical course of the Woman's Health and Diseases Nursing course, and that the stressors and coping strategies were similar across genders. In the clinical training for the Woman's Health and Diseases Nursing course lectures should be aware of possible stressors and, if necessary, should help students in positive coping.
\end{abstract}

Keywords: Coping Strategies; Gender; Nursing Clinical Course; Stress; Woman's Health and Diseases Nursing

\footnotetext{
1 The Our research Presented at the 4 th World Conference on Psychology Couselling and Guidance, 24-26 May 2013, Istanbul Turkey.

2 Ph.D., RN, Department of Obstetric and Gynecology Nursing, Marmara University, Istanbul, Turkey dilekcp@yahoo.com

3 Assist. Prof., Department of Obstetric and Gynecology Nursing, Abant İzzet Baysal University, Bolu Health School, Bolu Turkey nevincitak@yahoo.com

4 Prof. Dr., Department of Obstetric and Gynecology Nursing, Marmara University, Istanbul, Turkey nuranko2002@yahoo.com
} 
Coşkuner Potur, D., Çitak Bilgin, N., \& Kömürcü, N. (2015). Evaluating nursing students clinic stress, and coping with stress during the clinic first day of the Woman Health and Diseases Nursing clinical course. International Journal of Human Sciences, 12(1), 1169-1181. doi: 10.14687/ijhs.v12i1.2987

\section{Introduction}

Gender is the most important sociological characteristic of the nursing profession. Nursing is among the female-dominated professions thoughout the world. Today, the number of male nurses is ever increasing (Ünsal et al., 2010). In the profession of nursing, which started as providing help to the sick or those in need, men had taken the front role in the early ages while women either stood in the background or cooperated with men (Kaya et al., 2011). The literature indicates that males took an active part in caregiving before the work of Florence Nightingale during the Crimean War. However, by the mid-19 th century, Nightingale referred to nursing as intrinsic to women (Kaya et al., 2011; Duman, 2012; Karabacak, et al., 2012).

All educational institutions that train health care professionals have to provide training in a hospital environment in order to be able to provide care to healthy and non healthy individuals (Sar1, et al., 2008). Therefore, the importance of clinical training in nursing education is indisputable (Sendir \& Acaroğlu, 2007). Clinical training aims to improve the critical thinking, analysis, psychomotor, communication and management skills of the nursing student as well as increasing confidence in the course of the profession (Sar1, et al., 2008). However, studies have found that clinical experience causes stress in students (Admi, 1997; Burnard, et al., 2008; Cahn et al., 2009; Chesse-Smyth, 2005; Gorostidi, et al., 2007; Shaban et al., 2012). Stress is identified as an important psychosocial factor affecting the well being and academic performance of students (Atay \& Yilmaz, 2011).

The presence and level of stress in students may positively or negatively affect thinking and learning. High levels of stress are known to hamper learning, whereas low levels are known to motivate. Stressors in clinical environments can be termed as students having a hard time using the theoretical knowledge they have acquired, difficulty in adapting to the hospital, lack of clinical experience, high expectations from the tutor, and being present in unusual and unfamiliar situations (Sendir \& Acaroğlu, 2007; Inoue, et al., 2006).

Men joining nursing training has created different stressors in the clinical environment both with regard to the male students and the patient population. Especially in the applied parts of the Woman's Health And Diseases Nursing Course, the patient population being entirely female is a stressor for male students. When studies about male nurses in the field of woman's health are examined, it can be seen that the opinions of the female patients about the male nurses (Duman, 2012; Inoue, et al., 2006; Morin, et al., 1999; Taşç1, 2007a; Tezel, et al., 2008) and the experience of male nurses (Eswi \& El-Sayed, 2011; Patterson \& Morin, 2002; Taşç1, 2007b; Tzeng, et al., 2009) in the field are the most widely questioned topics. 
Coşkuner Potur, D., Çitak Bilgin, N., \& Kömürcü, N. (2015). Evaluating nursing students clinic stress, and coping with stress during the clinic first day of the Woman Health and Diseases Nursing clinical course. International Journal of Human Sciences, 12(1), 1169-1181. doi: 10.14687/ijhs.v12i1.2987

The fact that the clinical course of the Woman's Health and Diseases Nursing course takes place in environments with high stress levels such as the delivery room, high risk pregnancies, and gynecology, and that the patient population consists entirely of women can affect the stress levels of students in these clinical course.

When the researches are investigated there are not found studies aiming to determine the stress levels, stressors, or coping of nursing students in the first clinical day of the Woman's Health And Diseases Nursing Course, which has an all-female patient population, has made us plan this study as a cross-sectional study.

\section{Research questions}

1. What are the first day stressors for male and female students in the clinical course of the Woman's Health and Diseases course?

2. What are the first day stress levels of male and female students in the clinical course of the Woman's Health and Diseases course? Is there a difference between genders?

3. What are the first day stress coping strategies for male and female students in the clinical course of the Woman's Health and Diseases course? Is there a difference between genders?

\section{Method and material}

\section{Research design}

The study was planned as a cross-sectional study aiming to determine the stressors, stress levels and coping strategies of students studying in the Nursing Department of the Health Sciences Faculty in the 2009-2010 academic year who were taking the Woman's Health and Diseases Nursing course in the first day of the clinical course of the relevant course. The Woman's Health and Diseases course is, by curriculum, given in the sophomore year in the spring semester. The clinical course of the course is performed in the same semester in 6 different state hospitals where students can gain nursing skills in the fields of obstetrics and gynecology. Thus, the study was performed in the spring semester of the 2009-2010 academic year.

\section{Study population and sample}

The population of the study consisted of 106 students studying in the Nursing Department of the Health Sciences Faculty of a state university in Istanbul in the 2009-2010 academic year who were taking the Woman's Health and Diseases Nursing course and were going to clinical course in six different state hospitals. Since the whole universe was reachable, no sample was selected and 
Coşkuner Potur, D., Çitak Bilgin, N., \& Kömürcü, N. (2015). Evaluating nursing students clinic stress, and coping with stress during the clinic first day of the Woman Health and Diseases Nursing clinical course. International Journal of Human Sciences, 12(1), 1169-1181. doi: 10.14687/ijhs.v12i1.2987

data was gathered from the whole universe. However, since 5 students didn't come to the applied course in the first day and 3 students didn't want to participate, the study was completed with 98 students $(92.4 \%$ response rate)

\section{Instruments}

\section{Student Information Form}

The student information form, which was developed by the researchers, included 20 questions and was administered to the students on the first day of clinical practice. The student information form aimed to evaluate the students' socio-demographic characteristics and situations which cause stress during clinical practice (the hospital, peers in the practice group, the patient group).

\section{Clinical Stress Questionnaire (CSQ)}

The clinical stress questionnaire (CSQ) is a self report likert -type instrument that was developed by Pagana in 1989 for determining the beginning stress value that is threatening or challenging to nursing students in their first clinical experience. The CSQ, whose Turkish validity and reliability was established by Sendir and Acaroğlu (2007), may be applied in all internal and operational clinics after the "student's first clinical practice day". The questionnaire has 4 subdimensions including threat, fight, damage and benefit emotions. Each item is assessed at 5 degrees and requires one of the options of 0-“none", 1-“ a little bit", 2-“moderate", 3-“much", 4-"too much" to be chosen. The score ranges between the least " 0 " and the most " 80 " based on points given for each item. Lower scores indicate lower stress levels while higher scores indicate higher stress levels. In order to use the CSQ on the first day of the Woman's Health and Diseases Nursing course's clinical practice, permissions were obtained from Sendir and Acaroglu, who conducted the Turkish validity and reliability study of the CSQ. Sendir and Acaroglu had found that the CSQ's Cronbach's $\alpha$ coefficient was 0.70 . In the current study, the CSQ's Cronbach's $\alpha$ coefficient was found to be 0.72 .

\section{COPE Assessment Scale (for coping strategies)}

The COPE assessment scale was developed by Carver and colleagues in 1989 (Carver, et al., 1989). Ağargün et al. (2005) translated the scale into Turkish and conducted validity and reliability studies for the scale. This scale aims to examine how people react when confronted with a difficult 
Coşkuner Potur, D., Çitak Bilgin, N., \& Kömürcü, N. (2015). Evaluating nursing students clinic stress, and coping with stress during the clinic first day of the Woman Health and Diseases Nursing clinical course. International Journal of Human Sciences, 12(1), 1169-1181. doi: $10.14687 /$ ijhs.v12i1.2987

situation that causes stress. The scale consist of 60 questions and 15 sub-scales. Each of these subscales give information about different strategies for coping with stress. A high score obtained from a subscale implies that the particular strategy is used more often (A ğargün, et al., 2005). In the current study, the COPE's Cronbach's $\alpha$ coefficient was found to be 0,82 .

\section{Ethical considerations}

In all stages of the study, ethical principles were carefully taken into consideration. Students were told that they could quit the study at any time during the data collection period. Permission to conduct the study and access to the nursing students were obtained from the Dean of Health Sciences School.

\section{Data analysis}

Data analyses were carried out using the Statistical Software Package for the Social Science (SPSS), version 15.0. All data were examined with percentages, chi-square analysis, the MannWhitney U test and Cronbach's alpha coefficients. The accepted confidence interval was $95 \%$ and the significance level for all analyses was set at $\mathrm{p}<0.05$.

\section{Results}

\section{Sociodemographic characteristics}

In our study, most of the students were female (78.6\%). The mean age of female students was $20.39 \pm 1.90$ years (range 19-34 years). The mean age of male students was $21.10 \pm 1.17$ years (range 19-24 years). Bivariate analysis showed that sociodemographic characteristics (family type, high school, residence, smoking, level of income) for female and male students were similar. None of the students was married.

As shown in Table 1, stress sources (not introducing the hospital, difficulty in communication with the clinic staff, and difficulty in accessing the hospital, communicate with peers in the practice group, the large number of students in the practice group, difficulty in communicating with the instructor, etc.) of male and female nursing students were compared and found to be statistically similar $(\mathrm{p}>0.05)$. All of the female students did not experience stress because the patient group consisted of women; whereas approximately half of the male students $(47.6 \%)$ reported this to be a source of stress and there was a statistically significant difference between the two groups $(\mathrm{p}<0.01)$. All of the male students did not experience difficulty in duty sharing, but $17(22.7 \%)$ female students reported difficulty in duty sharing, reported this to be a 
Coşkuner Potur, D., Çitak Bilgin, N., \& Kömürcü, N. (2015). Evaluating nursing students clinic stress, and coping with stress during the clinic first day of the Woman Health and Diseases Nursing clinical course. International Journal of Human Sciences, 12(1), 1169-1181. doi: 10.14687/ijhs.v12i1.2987

source of stress and there was a statistically significant difference between the two groups $(\mathrm{p}<$ 0.05). In addition, the majority of male students (76.2\%) reported that they were subject to gender discrimination and $61.9 \%$ of the male students stated that patients' gender discrimination was a source of stress for them; and it was determined that there was a significant difference between the male and female students $(\mathrm{p}<0.001)$. The students' patients group related stress sources such as worrying about harming, feeling of not being able to help, fear of making a mistake, and difficulty in communication with the patients were compared and it was observed that there was no statistically significant difference between the groups $(\mathrm{p}>0.05)$.

Table 1. Comparison of female and male nursing students' stress sources

\begin{tabular}{|c|c|c|c|c|c|c|c|}
\hline \multirow[t]{2}{*}{ Stress sources } & \multicolumn{2}{|c|}{$\begin{array}{c}\text { Female student } \\
\quad(\mathrm{n}=77)\end{array}$} & \multicolumn{2}{|c|}{$\begin{array}{c}\text { Gender } \\
\text { Male student } \\
(\mathrm{n}=21)\end{array}$} & \multicolumn{2}{|c|}{ Total $(n=98)$} & $\boldsymbol{P}\left(\chi^{2}\right)$ \\
\hline & $\mathbf{n}$ & $\%$ & $\mathbf{n}$ & $\%$ & $\mathbf{n}$ & $\%$ & \\
\hline \multicolumn{8}{|c|}{ Not introducing the hospital } \\
\hline Yes & 30 & 39.0 & 8 & 38.1 & 38 & 38.8 & \multirow[t]{2}{*}{$0.05(0.05)$} \\
\hline No & 47 & 61.0 & 13 & 61.9 & 50 & 61.2 & \\
\hline \multicolumn{8}{|c|}{ Difficulty in communication with clinical staff } \\
\hline Yes & 37 & 48.1 & 8 & 38.1 & 45 & 45.9 & \multirow[t]{2}{*}{$0.05(0.659)$} \\
\hline No & 40 & 51.9 & 13 & 61.9 & 53 & 54.1 & \\
\hline \multicolumn{8}{|c|}{ Difficulty in accessing to the hospital } \\
\hline Yes & 15 & 19.5 & 11 & 52.4 & 26 & 26.5 & \multirow[t]{2}{*}{$0.05(9.163)$} \\
\hline No & 62 & 80.5 & 10 & 47.6 & 72 & 73.5 & \\
\hline \multicolumn{8}{|c|}{ Not able to communicate with friends in the clinic } \\
\hline Yes & 5 & 6.5 & 0 & 0 & 5 & 5.1 & \multirow{2}{*}{0.05 (fisher exact) } \\
\hline No & 72 & 93.5 & 21 & 100.0 & 93 & 94.9 & \\
\hline \multicolumn{8}{|c|}{ Difficulty in duty sharing } \\
\hline Yes & 17 & 22.1 & 0 & 0 & 17 & 17.3 & \multirow{2}{*}{$\begin{array}{l}0.019 \text { (fisher } \\
\text { exact) }\end{array}$} \\
\hline No & 60 & 77.9 & 21 & 100.0 & 81 & 82.7 & \\
\hline \multicolumn{8}{|c|}{ Excess of the number of students } \\
\hline Yes & 17 & 22.1 & 7 & 29.2 & 24 & 24.5 & \multirow[t]{2}{*}{$0.05(0.288)$} \\
\hline No & 60 & 77.9 & 14 & 66.7 & 74 & 75.5 & \\
\hline \multicolumn{8}{|c|}{ Difficulty in communication with instructor } \\
\hline Yes & 16 & 20.8 & 6 & 28.6 & 22 & 22.4 & \multirow[t]{2}{*}{$0.05(0.448)$} \\
\hline No & 61 & 79.2 & 15 & 71.4 & 76 & 77.6 & \\
\hline \multicolumn{8}{|c|}{ Working with female patients } \\
\hline Yes & 0 & 0 & 10 & 47.6 & 10 & 10.2 & \multirow{2}{*}{$\begin{array}{l}0.001 \quad \text { (fisher } \\
\text { exact) }\end{array}$} \\
\hline No & 77 & 100.0 & 21 & 52.4 & 88 & 89.8 & \\
\hline \multicolumn{8}{|c|}{ Gender discrimination } \\
\hline Yes & 11 & 14.3 & 13 & 61.9 & 24 & 24.5 & \multirow[t]{2}{*}{$0.001(20,233)$} \\
\hline No & 66 & 85.7 & 8 & 38.1 & 74 & 75.5 & \\
\hline \multicolumn{8}{|c|}{ Worrying about harming } \\
\hline Yes & 26 & 33.8 & 6 & 28.6 & 32 & 32.7 & \multirow[t]{2}{*}{$0.05(0.202)$} \\
\hline No & 51 & 66.2 & 15 & 71.4 & 66 & 67.3 & \\
\hline \multicolumn{8}{|c|}{ Feeling of not being able to help } \\
\hline Yes & 19 & 24.7 & 4 & 19.0 & 23 & 23.5 & \multirow[t]{2}{*}{$0.05(0.291)$} \\
\hline No & 58 & 75.3 & 17 & 81.0 & 75 & 76.5 & \\
\hline
\end{tabular}


Coşkuner Potur, D., Çitak Bilgin, N., \& Kömürcü, N. (2015). Evaluating nursing students clinic stress, and coping with stress during the clinic first day of the Woman Health and Diseases Nursing clinical course. International Journal of Human Sciences, 12(1), 1169-1181. doi: 10.14687/ijhs.v12i1.2987

\begin{tabular}{lccccccc}
\hline Fear of making mistake & & & & & & & \\
Yes & 28 & 36.4 & 4 & 19.0 & 32 & 32.7 & $0.05(2.250)$ \\
No & 49 & 63.6 & 17 & 81.0 & 66 & 67.3 & \\
Difficulty in communication with patients & & & & & \\
Yes & 5 & 6.5 & 5 & 23.8 & 10 & 10.2 & $0.05(5.399)$ \\
No & 72 & 93.5 & 16 & 76.2 & 88 & 89.8 & \\
\hline
\end{tabular}

Table 2 shown the stress levels on the Woman's Health And Disease Nursing clinical course clinic first day according to gender. There was no significant difference in CFD stress levels between the male and female students ( $p>0.05)$. When we evaluated the CSQ sub dimensions, we determined that male students obtained higher scores from the benefit sub scale compared to female students and that there was a significant difference between the groups $(\mathrm{p}<0.05)$.

Table 2. Comparison of Woman's Health And Disease Nursing clinical course CSQ scores on the according to gender

\begin{tabular}{|c|c|c|c|c|c|c|}
\hline \multirow[t]{2}{*}{$\begin{array}{l}\text { The Clinical Stres } \\
\text { Questionnaire }\end{array}$} & \multicolumn{2}{|c|}{$\begin{array}{c}\begin{array}{c}\text { Female student } \\
\mathrm{n}=77\end{array} \\
\text { che }\end{array}$} & \multicolumn{2}{|c|}{$\begin{array}{l}\text { Male student } \\
n=21\end{array}$} & \multicolumn{2}{|c|}{$P^{*}$} \\
\hline & $\bar{x}$ & $S d$ & $\bar{x}$ & $S d$ & $Z^{a}$ & $p$ \\
\hline Threat & 9,55 & 4,24 & 8,05 & 4,68 & $-1,255$ & 0,209 \\
\hline Challenge & 11,62 & 5,30 & 13,67 & 5,31 & $-1,618$ & 0,106 \\
\hline Benefit & 2,52 & 1,90 & 3,52 & 2,08 & $-2,112$ & $0,035^{*}$ \\
\hline Harm & 6,06 & 3,48 & 7,67 & 4,00 & $-1,781$ & 0,075 \\
\hline Total & 30,18 & 8,31 & 33,52 & 11,66 & $-1,483$ & 0,138 \\
\hline
\end{tabular}

${ }^{a}$ Mann-Whitney U

In Table 3, status of coping with stress in the Woman's Health and Disease Nursing clinical course were compared. The male and female students obtained similar scores from the Problem focused, Emotion focused, Non-functional coping strategies, and the total coping scale, and it was determined that there is no significant difference between the groups $(p>0.05)$.

Table 3. Comparison of Woman's Health And Disease Nursing clinical course COPE scores on the according to gender

\begin{tabular}{|c|c|c|c|c|c|c|}
\hline \multirow[t]{2}{*}{ COPE } & \multicolumn{2}{|c|}{$\begin{array}{c}\text { Female student } \\
\mathrm{n}=77\end{array}$} & \multicolumn{2}{|c|}{$\begin{array}{l}\text { Male student } \\
\mathrm{n}=21\end{array}$} & \multicolumn{2}{|c|}{$p$} \\
\hline & $\bar{x}$ & $S d$ & $\bar{x}$ & $S d$ & $U / Z^{a}$ & $p$ \\
\hline $\begin{array}{l}\text { Problem focused } \\
\text { strategies }\end{array}$ & 55,79 & 6,88 & 56,76 & 6,37 & $-0,416$ & 0,677 \\
\hline Active coping & 11,56 & 1,82 & 11,00 & 1,61 & $-1,373$ & 0,170 \\
\hline Planning & 12,04 & 2,12 & 12,19 & 2,13 &,- 434 & 0,665 \\
\hline Restraint coping & 9,51 & 1,50 & 10,90 & 1,33 & $-3,673$ & 0,001 \\
\hline $\begin{array}{l}\text { Seeking social support for } \\
\text { instrumental }\end{array}$ & 12,97 & 2,18 & 11,90 & 1,92 & $-2,166$ & 0,030 \\
\hline $\begin{array}{l}\text { Suppression of competing } \\
\text { activities }\end{array}$ & 9,71 & 1,84 & 10,76 & 1,89 & $-2,532$ & 0,011 \\
\hline
\end{tabular}


Coşkuner Potur, D., Çitak Bilgin, N., \& Kömürcü, N. (2015). Evaluating nursing students clinic stress, and coping with stress during the clinic first day of the Woman Health and Diseases Nursing clinical course. International Journal of Human Sciences, 12(1), 1169-1181. doi: 10.14687/ijhs.v12i1.2987

\begin{tabular}{|c|c|c|c|c|c|c|}
\hline $\begin{array}{lll}\begin{array}{l}\text { Emotion } \\
\text { strategies }\end{array} & \text { foceused } & \text { coping } \\
\end{array}$ & 54,38 & 6,05 & 53,00 & 6,90 & $-0,702$ & 0,482 \\
\hline Positive reinterpretation & 12,57 & 1,75 & 13,14 & 1,45 & $-1,319$ & 0,187 \\
\hline Turning to religion & 11,73 & 2,81 & 11,86 & 2,85 & $-0,162$ & 0,872 \\
\hline Humour & 8,04 & 2,72 & 8,00 & 2,81 & $-0,057$ & 0,955 \\
\hline $\begin{array}{l}\text { Seeking of emotional social } \\
\text { support reasons }\end{array}$ & 11,70 & 2,84 & 10,62 & 2,51 & $-1,447$ & 0,148 \\
\hline Acceptence & 10,34 & 1,91 & 9,38 & 2,29 & $-1,654$ & 0,098 \\
\hline $\begin{array}{l}\text { Non-functional } \\
\text { strategies }\end{array}$ & 39,45 & 6,12 & 38,19 & 8,36 & $-0,993$ & 0,321 \\
\hline Mental disengagement & 10,62 & 1,92 & 9,57 & 2,18 & $-2,046$ & 0,041 \\
\hline $\begin{array}{l}\text { Focusing on and venting of } \\
\text { emotions }\end{array}$ & 10,83 & 1,92 & 9,24 & 2,64 & $-2,344$ & 0,019 \\
\hline Denial & 6,64 & 2,09 & 6,76 & 1,84 & $-0,233$ & 0,823 \\
\hline Substance use & 4,62 & 2,07 & 5,24 & 2,38 & $-1,581$ & 0,114 \\
\hline Behavioural disengagement & 6,74 & 2,03 & 7,38 & 2,41 & $-1,081$ & 0,280 \\
\hline COPE TOTAL & 152,49 & 13,59 & 150,48 & 17,08 & $-0,615$ & 0,539 \\
\hline
\end{tabular}

However, it was found that restraint coping and suppression of competing activities, which are among the problem focused and positive coping strategies, were used more frequently by male students and that there was a statistically significant difference between the male and female students $(\mathrm{p}<0.05)$. On the other hand, it was determined that seeking social support for instrumental reasons, which is one of the positive problem focused coping strategies, was used more frequently by female students compared to their male counterparts and that there was a significant difference between the groups $(\mathrm{p}<0.05)$. Female students obtained higher Focusing on and venting of emotions and Mental disengagement scores, which are non-functional coping strategies, compared to male students and the difference between the groups was statistically significant $(\mathrm{p}<0.05)$.

\section{Discussion}

The stressors in each course can be different, and which situation cats as a stressor tends to differ in time. For example, while in the clinical course of Fundamentals of Nursing being in the hospital environment for the first time or applying injections under the supervision of a lecturer act as stressors, later providing post operational care to patients just out of anesthesia, caring for a bleeding or dismembered patient in the ER internship, or observing a resuscitation in intensive care become stressors. Nursing students are expected to get better in coping with stressors as they gain experience in working in those fields. In this cross-sectional study which aims to determine the stress sources, stress levels and the status of coping with stress during the clinic first day of the woman health and diseases nursing clinical course, approximately half of the male students reported that having a female patient group was a source of stress and three-fourths of male 
Coşkuner Potur, D., Çitak Bilgin, N., \& Kömürcü, N. (2015). Evaluating nursing students clinic stress, and coping with stress during the clinic first day of the Woman Health and Diseases Nursing clinical course. International Journal of Human Sciences, 12(1), 1169-1181. doi: $10.14687 /$ ijhs.v12i1.2987

students stated that the patient group's gender bias was a source of stress; and it was determined that there was a significant difference between the female and male students There was no significant difference in clinic first day stress levels between the male and female students. In addition, it was demonstrated that male students used beneficial coping strategies such as restraint coping and suppression of competing activities better than females, whereas female students used non-functional coping strategies better. However, the coping strategies of male and female students were found to be similar in general.

In a study by Ünsal et al. (2010), which aimed to determine the thoughts of employees in different professions about male nurses, it was demonstrated that the public's reaction to male nurses was positive, the majority of the participants thought that males can work as nurses, and the participants supported the idea of males becoming nurses as well. A large number of national and international studies which recruited different sample groups support the study's findings (Ünsal, et al., 2010; Arıkan, et al., 2000; Kocaer, et al., 2004; Meadus \& Twomey, 2007; Özbasaran, et al., 200227). However, Wood (2004) found that male nursing students in the United States faced more difficulties than did females (Wood, 2004). For example, they were rejected by maternity clients or their families and nor allowed to practice in certain care areas. Morin et al. (1999) studied women's responses to care provided by male nursing students. They found that women expressed a preference for female students because of the private nature of such care (Morin, et al., 1999). Male nursing students in Turkey have faced the same situation. In a study by Duman (2012), it was found that all of the participating women did not want to receive care from male nurses throughout the pregnancy and labor period. Nearly nine of the ten pregnant women emphasized that nursing was a profession that only women could do, that male nurses could not work at the maternity and childbirth services and that they could not receive care from male nurses throughout the pregnancy and labor period (96.7\%). Similarly, in a study by Kocaer et al. (2004), it was determined that approximately half of the nursing students did not want male nurses to work in labor services (Kocaer, et al., 2004). In the present study, it was shown that approximately half of the male students regarded working with a female patient group as a source of stress and the majority of male students thought they were subject to gender bias. Despite the studies yielding positive results about males' participation in the nursing profession, the field of woman's health is largely affected by gender bias throughout the world. Female patients do not want to receive care from male nurses and in turn, male students experience stress because of the gender bias.

Moderate levels of stress have positive effects on an individual's motivation due to its stimulating affect. However, it has been demonstrated that high levels of stress is an important 
Coşkuner Potur, D., Çitak Bilgin, N., \& Kömürcü, N. (2015). Evaluating nursing students clinic stress, and coping with stress during the clinic first day of the Woman Health and Diseases Nursing clinical course. International Journal of Human Sciences, 12(1), 1169-1181. doi: $10.14687 /$ ijhs.v12i1.2987

factor which prevents academic success and it also affects the student's clinical performance and the ability to develop skills (Atay \& Yllmaz, 2011). In our study, it was determined that the students experienced moderate levels of clinical stress reported. This finding is similar to the results of studies conducted by Chan et al. and Karabacak et al. On the other hand, the same scale was used other research showed that, the clinical stress levels of our participants is lower than those of Atay and Yllmaz's (2011). This difference can be explained by the facts that Atay and Yilmaz used the CSQ for the clinical practice of the course Fundamentals of Nursing and that the students who participated in the present study had more clinical experience since they are in $2^{\text {nd }}$ grade.

Benefiting from various coping strategies in order to minimize or eliminate the negative effects of stressors is a universal attitude. "Coping" can be defined as an individual's resistance to stressful situations or factors and all of his/her cognitive, emotional, and behavioral reactions aimed at resisting stress (A ğargün, et al., 2005). Although students cannot avoid stressors, their ability to cope is important in achieving success in their academic and social environments (Watson, et al., 2009). The effects of stress on health depend on the adequacy of coping behaviors. Coping behaviors play a vital part in the stress adjustment process (Shaban, et al., 2012). In our study, it was found that the students experienced moderate levels of stress on the first day of the Woman's Health and Diseases Nursing clinical course. However, male students emphasized that they were subject to gender bias and more than half of the male students regarded gender bias as a source of stress. When we examined the students' status of coping with stress, we observed that male students more frequently used restraint coping and suppression of competing activities, which are among the problem focused and positive coping strategies; whereas female students more frequently used Focusing on and venting of emotions and Mental disengagement, which are nonfunctional coping strategies. This finding can be explained by the fact that women's emotional characteristics reflect on their ways of coping and male students develop coping strategies which are appropriate for the type of stress they experience. In a study by Sar1 et al. (2008), which examines the ways of coping with stress in female midwifery students, it was found that negative coping strategies were used more frequently on the first clinical day. This finding is similar to our results. Although male students developed more appropriate coping strategies in the process of coping with stress on the first clinical day compared to female students; there was no significant difference between the male and female students' coping strategies, which is in line with Shaban et al.'s (2012) findings.

\section{Conclusion}


Coşkuner Potur, D., Çitak Bilgin, N., \& Kömürcü, N. (2015). Evaluating nursing students clinic stress, and coping with stress during the clinic first day of the Woman Health and Diseases Nursing clinical course. International Journal of Human Sciences, 12(1), 1169-1181. doi: 10.14687/ijhs.v12i1.2987

In our study, half of male students experience stress because the patient group consisted of women, the majority of male students reported that they were subject to gender discrimination and $61.9 \%$ of the male students stated that patients' gender discrimination was a source of stress for them. It was found that students experienced medium levels of stress in the first day of the clinical course of the Woman's Health and Diseases Nursing course, and that the stressors and coping strategies were similar across genders. As an important results, male students were found to use problem oriented positive coping strategies Restraint coping and Suppression of competing activities better than female students. In light of findings from the current study, the following suggestions have emerged:

- Students who have previously gone to the clinical course of this course should be enabled to share their experiences with the students.

- Before the clinical training for the Woman's Health and Diseases Nursing course, the students should be provided information in a classroom or laboratory about possible difficulties or stressors they could face in the hospital.

- Male students experience stress due to having a patient group of women in the clinical practice of the course Women's Health and Diseases; therefore, during the first clinical days, male students should be supported by lecturers and clinical nurses in patient care.

- Nursing is not exclusive to females and men can also be nurses. Public awareness on this topic should be raised.

- Female students who use malfunctional coping strategies when faced with stressors in the clinical environment should be encouraged to use problem-focused coping strategies by lecturers.

- In the clinical training for the Woman's Health and Diseases Nursing course lectures should be aware of possible stressors and, if necessary, should help students in positive coping.

\section{Acknowledgments}

We wish to thank all students who so willingly participated in this study. We also wish to acknowledge our statistics expert Assist Prof Dr Ömer Uysal. The authors declare that there are no competing interest, and also that there were no funding organizations for this study. 
Coşkuner Potur, D., Çitak Bilgin, N., \& Kömürcü, N. (2015). Evaluating nursing students clinic stress, and coping with stress during the clinic first day of the Woman Health and Diseases Nursing clinical course. International Journal of Human Sciences, 12(1), 1169-1181. doi: 10.14687/ijhs.v12i1.2987

\section{References}

Admi, H. (1997). Nursing students' stress during the initial clinical experience. Journal of Nursing Education, 36(7): 323-327

Ağargün, M.Y., Beşiroğlu, L., Kıran, Ü.K., Özer, Ö.A., Kara, H. (2005). Cope (Başa çıkma tutumlarını değerlendirmeölçeği): Psikometrik özelliklere ilişkin bir ön çalışma. (The psychometric properties of the COPE inventory in Turkish sample: a preliminary research). Turkish Anatolian Journal of Psychiatry, 6: 221-226

Arıkan, D., Karaman, Z., Yağc1, G. (2000). Hemşirelik yüksekokulu öğrencilerinin eğitimde ve mesleki alanda erkekhemşire adaylarına bakış açısı. (The perspective of nursing college's students to male nurses on educational and professional life). Journal of Anatolia Nursing and Health Sciences, 3(1): 36-43

Atay, S., \& Yılmaz, F. (2011). Sağlık Yüksekokulu öğrencilerinin ilk klinik stres düzeyleri. (The first stress levels of thestudents of vocational higher school of health). Journal of Anatolia Nursing and Health Sciences, 14(4): 32-37

Burnard, P., Edeards, D., Bennet, K., et al. (2008). A comparative, longutidinal study of stress in student in fivecountries: Albania, Brunei, The Czech Republic, Malta and Wales. Nurse Education Today, 28: 134-145

Carver, C.S., Scheier, M.F., Weintraub, J.K. (1989). Assessing coping strategies: a theoretically based approach. Journalof Personality and Social Psychology, 56(2): 267-283

Chan, K.L, Winnie, K.W., Fong, D. (2009). Hong Kong baccalaureate nursing students' stress and their coping strategies in clinical practice. Journal of Professional Nursing, 25(5): 307-313

Chesser-Smyth, P. (2005). The lived experiences of general student nurses on their first clinical placement: aphenomenological study. Nurse Education in Practice, 5(6): 320-327.

Duman, N.B. (2012). The attitudes and opinions of women in Turkey about the male nurses who worked at thematernity and childbirth service. International Journal of Business and Social Science, 3(19): 101-106

Eswi, A., El-Sayed, Y. (2011). The experience of Egyptian male student nurses during attending maternity nursing clinical course. Nurse Education in Practice, 11(12): 93-98

Gorostidi, X.Z., Egilegor, X.H., et al. (2007) Stress sources in nursing practice. Evolution during nursing training. Nurse Education Today, 27(7): 777-787

Inoue, M., Chapman, R., Wynaden, D. (2006). Male nurses' experiences of providing intimate care for women clients. Journal of Advenced Nursing, 55(5): 559-67

Karabacak, Ü., Uslusoy, E., Alpar, Ş.E., Bahçecik, N. (2012 a) Image of nursing hela by nursing students according to gender: A qualitative study. International Journal of Nursing Practice, 18:537-44

Karabacak, Ü., Uslusoy, E., Şenturan, L., Alpar, Ş.E., Yavuz, D. (2012 b) First day in clinical practice: evaluating stress of nursing students and their ways to cope with it. Healthmed, 6(2): 596-602

Kaya, N., Turan, N., Öztürk, A (2011).. Türkiye'de erkek hemşire imgesi. (Men nurse image in Tukey). International Journal of Human Sciences, 8(1): 16-30

Kocaer, Ü., Öztop, T., Usta, N. et al. (2004). Hemsirelik mesleginde erkek üyelerin yeri. (Male members in nursing). Journal of Anatolia Nursing and Health Sciences, 7(2): 1-7.

Meadus, R.J., Twomey, J,C. (2007). Men in nursing: making the right choice. Can Nurse, 103(2): 1316.

Morin, K.H., Patterson, B.J., Kurts, B., Brzowski, B. (1999). Mothers' responses to care given by male nursing students during and after birth. Image Jornal of Nursing Scholarship, 31(1): 83-87 
Coşkuner Potur, D., Çitak Bilgin, N., \& Kömürcü, N. (2015). Evaluating nursing students clinic stress, and coping with stress during the clinic first day of the Woman Health and Diseases Nursing clinical course. International Journal of Human Sciences, 12(1), 1169-1181. doi: 10.14687/ijhs.v12i1.2987

Özbasaran, F., Taspınar, A., Çakmakçı, A. (2002). Hastalar kendilerine bakım verenlerin cinsiyeti konusunda ne düsünüyorlar? (What are patients think about the gender of the people who look after them?). Journal of Anatolia Nursing and Health Sciences, 5(2): 1-7.

Patterson, B.J., Morin, KH. (2002). Perceptions of the maternal-child clinical rotation: The male student nurse experience. Journal of Nursing Education, 41(6): 266-272

Sarı, D., Turgay, A.S., Genç, R.E. (2008). İlk defa invaziv girişim yapacak ebelik öğrencilerine uygulama öncesi verilen farklı öğretimin anksiyete düzeyine etkisi. (Effect on anxiety level of distinct education that given application previous to midwifery students will do firts time invasive attempt). Journal of Ege University Nursing Faculty, 24(3): 1-8

Sendir, M., Acaroğlu, R (2007). Reliability and validity of Turkish version of clinical stress questionnaire. Nurse Education Today, 28(6):737-43

Shaban, I.A., Khater, W.A., Akhu-Zaheya, LM. (2012) Undergraduate nursing students stress sources and coping behaviours during their initial period of clinical training: A Jordanian perspective. Nurse Education in Practice, 12(4):204-209

Sheu, S., Lin, H.S., Hwang, S.L. (2002). Perceived stres and physio-psycho-social status of nursing students during their initial period of clinical practice: the effect of coping behaviors. International Journal of Nursing Studies, 39(2): 165-75

Taşçı, D.K. (2007 a ). Kadın Doğum servislerinde yatan hastaların erkek hemşireler hakkında düşünceleri. (Inpatients on obstetrics and gynecology services opinions about male nurses). Journal of Anatolia Nursing and Health Sciences, 10(2):12-19

Taşçı, D.K.( 2007 b) Öğrencilerin kadın hastalıkları ve doğum dersine ilişkin dönem başlangıcı ve bitişindeki görüşleri. (Students' opinions about obstetric and gynecologic nursing course at the begining and end of of the semester). Journal of Anatolia Nursing and Health Sciences, 10(3): 45-51

Tezel, A., Akpınar, R.B., Yurtaş, A., Çelebioğlu, A. (2008). Hastalar erkek hemşireleri kabul edecekler mi? (Will patient accept the male nurses?). Tükiye Klinikleri J Med Ethics, 16(1): 13-18

Tzeng, Y.L., Chen, J.Z., Tu, H.C., Tsai, T.W. (2009). Role strain of different gender nursing students in obstetrics practice: a comparative study. Journal of Nursing Research, 17(1): 1-8

Ünsal, A., Akalın, İ., Yılmaz, V. (2010). Farklı meslek çalışanlarının erkek hemşirelere ilişkin görüşleri. (Opinions ofdifferent profession working people related men nurse). International Journal of Human Sciences, 7(1): 420-31

Watson, R., Gardiner, E., Hogston, R., et al. (2009). A longitudinal study of stress and psychological distress in nurses and nursing students. Journal of Clinical Nursing, 18(2): 270-278.

Wood T L. Male in nursing: Perceptions of their education experience. Unpublished doctoral dissertation, University of Saint Louis, Missouri. 2004 